4 Murray RO. Radiological bone changes in Cushing's syndrome and steroid therapy. Br f Radiol 1960;33:1-19.

5 Baylink DJ. Glucocorticoid-induced osteoporosis. N Engl f Med 1983;309:306-8.

6 Hahn TJ, Boisseau VC, Avioli LV. Effect of chronic corticosteroid administration on diaphyseal and metaphyseal bone mass. $\mathcal{f}$ Clin Endocrinol Metab 1974;39:274-82.

7 Deding A, Taigaard S, Jensen MK, Rodbro P. Bone changes during prednisone treatment. Acta Med Scand 1977;202:253-5.

8 Adinoff AD, Hollister JR. Steroid induced fractures and bone loss in patients with asthma. $N$ Engl f Med 1983:309:265-8.

9 Gluck OS, Murphy WA, Hahn TJ, Hahn B. Bone loss in adults receiving alternate day glucocorticoid therapy. Arthritis Rheum 1981;24:892-8.

10 Ruegsegger P, Medici TC, Anliker M. Corticosteroid induced bone loss. A longitudinal study of alternate day therapy in patients with bronchial asthma using computed tomography. Eur $\mathcal{F}$ Clin Pharmacol 1983:25:615-20.

11 Mueller MN. Effects of corticosteroids on bone mineral in rheumatoid arthritis and asthma. American fournal of Roentgenolog $1976 ; 12: 1300$

12 Mueller MN, Mazess RB, Cameron JR. Corticosteroid therapy accelerated osteoporosis in rheumatoid arthritis. In: Mazess RB, ed. International conference on bone mineral measurement. Washington, DC: US Department of Health, Education, and Welfare, 1974:195-6. (DHEW publication $75 / 683$.)

13 Reid DM, Nicoll JJ, Brown N, Smith MA, Tothill P, Nuki G. Bone mass in corticosteroid treated patients with rheumatoid arthritis, asthma and polymyalgia rheumatica. Scott Med $1985 ; 30: 54-5$

14 Kennedy NSJ, Eastell R, Ferrington CM, et al. Total body neutron activation analysis of calcium calibration and normalisation. Phys Med Biol 1982;27:697-707.

15 Reid DM, Kennedy NSJ, Smith MA, Tothill P, Nuki G. Total body calcium in rheumatoid arthritis: effects of disease activity and corticosteroid treatment. Br Med f 1982;285:330-2.

16 Ropes MW, Bennett GA, Cobb S, Jacox R, Jessar AR. Proposed diagnostic criteria for rheumatoid arthritis. Ann Rheum Dis 1959;18:49.

17 Hunder G, Hazelman BL. Giant cell arteritis and polymyalgia rheumatica. In: Kelley WN, Harris ED, Ruddy S, Sledge CB, eds. Textbook of rheumatology. Philadelphia: W B Saunders Co, 1985:1166-73.

18 Tothill P, Nicoll J, Kennedy NSJ, Smith MA, Reid DM, Nuki G. The in-vivo precision of total body calcium determinations by neutron activation analysis. In: Christiansen $C$, Arnaud $C D$, Nordin BEC, Parfitt AM, Peck WA, Riggs BL, eds. Osteoporosis. Denmark: Department of Clinical Chemistry, Glostrup Hospital, 1984:217-8.

19 Documenta Geigy. Chauvenet's criterion. In: Scientific tables. 5th ed. Basle: J R Geigy, 1956:47

20 Fourman P, Royer P. Calcium metabolism and the bone. Oxford: Blackwell, 1968:20.

21 Mazess RB, Peppler WW, Chestnut CH, Nelp WB, Cohn SH, Zanzi I. Total body bone mineral by dual photon absorptiometry. II Comparison with total body calcium by neutron activation analysis. Calcif Tissue Int 1981:33:361-3.
22 Cohn SH, Ellis KJ, Wallach S, Zanzi I, Atkins HL, Aloia JF. Absolute and relative deficit in total skeletal calcium and radial bone mineral in osteoporosis. $7 \mathrm{Nucl} \mathrm{Med} \mathrm{1974;15:428-35.}$

23 Eastell R, Kennedy NSJ, Smith MA, Simpson JD, Strong JA, Tothill P. The assessment of postmenopausal osteoporosis by total body neutron activation analysis. Metab Bone Dis Relat Res 1983;5:65-7

24 Ott SM, Murano R, Lewellen TK, Nelp WB, Chestnut CH. Total body calcium by neutron activation analysis in normals and osteoporotic populations: a discriminator of significant bone mass loss. I Lab Clin Med 1983;102:637-45.

25 Hahn TJ, Halstead LR, Baron DT. Effects of short term glucocorticoid administration on intestinal calcium absorption and circulating vitamin $\mathrm{D}$ metabolite concentrations in man. 7 Clin Endocrinol Metab 1981;52:111-5.

26 Hahn TJ, Halstead LR, Tietelbaum SL, Hahn BH. Altered mineral metabolism in glucocorticoid induced osteopenia: effect of 25 -hydroxyvitamin $\mathrm{D}$ administration. $\mathcal{f}$ Clin Invest 1979;64:655-65.

27 Dykman TR, Haralson KM, Gluck OS, et al. Effect of oral 1,25-dihydroxyvitamin D and calcium on gluco-corticoid induced osteopenia in patients with rheumatic diseases. Arthritis Rheum 1984;27:1336-43.

28 Tse CST, Bernstein IL. Corticosteroid aerosols in the treatment of asthma. Pharmacotherapy 1984;4:334-42.

29 Spector SL. The use of corticosteroids in the treatment of asthma. Chest 1985;87(suppl):73-9.

30 Wyatt R, Waschek J, Weinberger M, Sherman B. Effects of inhaled beclomethasone dipropionate and alternate-day prednisone on pituitary-adrenal function in children with chronic asthma. NEngl f Med 1978;299:1387-92.

31 Toogood JH, Lefcoe NM, Haines DSM, et al. Minimum dose requirement of steroid-dependent asthmatic patients for aerosol beclomethasone and oral prednisone. 7 Allergy Clin Immunol 1978;61:355-64.

32 Gaddie J, Petrie GR, Reid IW, et al. Aerosol beclomethasone dipropionate; a dose response study in chronic bronchial asthma Lancet 1973;ii:280-1.

33 Johansson SA, Anderson KE, Brattsand R, Gruvstad E, Hedner P. Topical and systemic glucocorticoid potencies of budesonide, beclomethasone dipropionate and prednisolone in man. Eur $\mathcal{Y}$ Respir Dis 1982;122(suppl):74-82.

34 Anonymous. High-dose corticosteroid inhalers for asthma. [Editorial.] Lancet 1984;ii: 23.

35 Lofdahl CG, Mellstrand T, Svedmyr N. Glucocorticoids and asthma. Studies of resistance and systemic effects of glucocorticoids. Eur $\mathcal{F}$ Respir Dis 1984;136(suppl):69-79.

36 Reid DM, Kennedy NSJ. Nicoll J, Smith MA, Tothill P, Nuki G. Total and peripheral bone mass in patients with psoriatic arthritis and rheumatoid arthritis. Clinical Rheumatology (in press).

37 Reid DM, Kennedy NSJ, Smith MA, et al. Bone loss in rheumatoid arthritis and primary generalised osteoarthrosis: effects of corticosteroids, suppressive anti-rheumatic drugs and calcium supplements. British fournal of Rheumatology 1986;25:253-9.

(Accepted 12 September 1986)

\title{
Association between liberalisation of Scotland's liquor licensing laws and admissions for self poisoning in West Fife
}

\author{
D B NORTHRIDGE， J MCMURRAY， A A H LAWSON
}

\begin{abstract}
Data were collected prospectively on 2868 consecutive patients admitted for self poisoning between 1971 and 1982. Analysis showed a dramatic increase in the frequency of alcohol taken in association with self poisoning, in both sexes, after the liberalisation of Scotland's liquor licensing laws. This increase, however, did not appear to affect the severity of overdoses or the outcome.

Total admission rates for self poisoning increased with relaxation of the liquor licensing laws, and since overdoses associated with alcohol tend to occur at night these impose considerable strain on casualty departments and acute admitting units.
\end{abstract}

\section{Introduction}

The Clayson committee examined alcohol related problems in Scotland in 1972 and concluded that "licensing, a negative and restrictive process, can play only a strictly limited part in the control

Milesmark Hospital, Dunfermline, Fife KY12 9NR

D B NORTHRIDGE, $M B, M R C P$, medical registra

J MCMURRAY, BSC, MRCP, medical registrar

A A H LAWSON, MD, FRCPED, consultant physician

Correspondence to: Dr Lawson of alcohol misuse." As a result of the committee's recommendations Scotland's liquor licensing laws were relaxed in December 1976, allowing bars to remain open for an extra hour in the evenings. The following year public houses were permitted to open on Sundays and some "all day licences" were granted.

The effects of these changes on alcohol related problems in Scotland have recently been examined. ${ }^{2}$ No increase in death rates from cirrhosis and alcoholism was found compared with England and Wales. There was a fall in the incidence of public order offences related to alcohol since the law was changed in 1976. A lag phase, however, would be expected before the death rate from cirrhosis began to rise, and numbers of deaths from alcoholism are very small. Convictions for public order offences may reflect policing policies as much as alcohol consumption. These deficiencies have been highlighted and recommendations made to consider data which reflect alcohol consumption in the community more accurately. ${ }^{3}$

This study examines the frequency of alcohol intake associated with admissions for self poisoning during the six year periods before and after the change in the law and the effects of alcohol on the medical outcome of these episodes.

\section{Present study and results}

Milesmark Hospital serves a mixed urban and rural population of roughly 130000 . All patients aged 12 and over with self poisoning are admitted to th 
acute medical unit. Data regarding the circumstances of each overdose have been recorded prospectively on punch cards since 1969 .

Confidence intervals for the present study were calculated using the difference between two proportions. ${ }^{4}$

A total of 1214 patients ( 393 male, 821 female) were admitted between January 1971 and December 1976, and 1654 (593 male, 1061 female) between January 1977 and December 1982. The age and sex distributions were similar in the two six year periods. Over half of the patients who took alcohol $(497 / 905 ; 55 \%)$ were admitted between midnight and 6 am compared with just over a quarter of those $(514 / 1963 ; 26 \%)$ who did not. This distribution was similar during both time periods and for both sexes.

Table I shows the proportions of patients taking alcohol with their overdose in each period; figure 1 shows the yearly trends. Between 1971 and $1976,29 \%$ of men took alcohol, and the figure rose to $52 \%$ for the period 1977 to 1982 . This increase of $23 \%$ had a $95 \%$ confidence interval of $17 \%$ to $29 \%$. For women there was a $21 \%$ increase from $14 \%$ to $35 \%$, the $95 \%$ confidence interval being $17 \%$ to $25 \%$. Since neither confidence interval included zero the increases were significant at the $5 \%$ level.

TABLE I-Proportions of patients taking alcohol with their overdose before and after change in licensing laws

\begin{tabular}{|c|c|c|c|c|}
\hline & \multicolumn{2}{|c|}{$1971-6$} & \multicolumn{2}{|c|}{$1977-82$} \\
\hline & $\begin{array}{c}\text { Total } \\
\text { admissions }\end{array}$ & $\begin{array}{l}\text { No }(\%) \text { of patients } \\
\text { taking alcohol }\end{array}$ & $\begin{array}{c}\text { Total } \\
\text { admissions }\end{array}$ & $\begin{array}{l}\text { No }(\%) \text { of patients } \\
\text { taking alcohol }\end{array}$ \\
\hline Males & 393 & $114(29 \cdot 0)$ & 593 & $306(51 \cdot 6)$ \\
\hline Females & 821 & $117(14 \cdot 3)$ & 1061 & $368(34 \cdot 7)$ \\
\hline
\end{tabular}

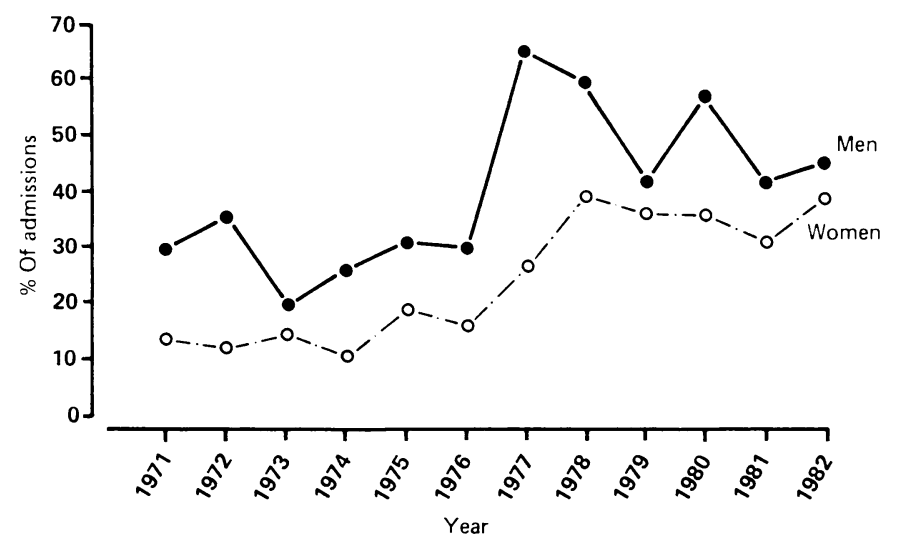

FIG 1-Percentages of patients admitted who took alcohol at time of self poisoning.

The total yearly admission rate for self poisoning was rising before 1976, but the rate of increase rose sharply after the change in the law and subsequently fell to previous levels (fig 2). In recent years there has been a fall in the incidence of overdoses with benzodiazepines, barbiturates, and dextropropoxyphene, drugs which interact adversely with alcohol..$^{5-7}$

Table II shows the grades of unconsciousness ${ }^{8}$ and proportions of patients requiring care of the airway or artificial ventilation. Table III presents these data in relation to patients who took and did not take alcohol at the time of self poisoning.

TABLE II-Numbers (percentages) of patients in coma grades 2 to 4 and numbers (percentages) of patients requiring protection of airway or artificial ventilation before and after change in licensing laws

\begin{tabular}{|c|c|c|c|c|c|c|c|}
\hline \multirow[b]{2}{*}{ Period } & \multirow{2}{*}{$\begin{array}{c}\text { Total } \\
\text { admissions }\end{array}$} & \multicolumn{3}{|c|}{ Coma grade } & \multirow{2}{*}{$\begin{array}{c}\text { Oro- } \\
\text { pharyngeal } \\
\text { airway }\end{array}$} & \multirow{2}{*}{$\begin{array}{l}\text { Endo- } \\
\text { tracheal } \\
\text { tube }\end{array}$} & \multirow{2}{*}{$\begin{array}{l}\text { Venti- } \\
\text { lator }\end{array}$} \\
\hline & & 2 & 3 & 4 & & & \\
\hline $1971-6$ & 1214 & $57(4 \cdot 7)$ & $122(10 \cdot 0)$ & $66(5 \cdot 4)$ & $61(5 \cdot 0)$ & $35(2 \cdot 9)$ & $11(0.9)$ \\
\hline $1977-82$ & & $128(7 \cdot 7)$ & $105(6 \cdot 3)$ & $69(4 \cdot 2)$ & $39(2 \cdot 4)$ & $49(3 \cdot 0)$ & $26(1 \cdot 6)$ \\
\hline
\end{tabular}

TABLE III-Numbers (percentages) of patients in coma grades 2 to 4 and numbers (percentages) of patients requiring protection of airway or artificial ventilation stratified according to whether alcohol was or was not used at time of self poisoning

\begin{tabular}{|c|c|c|c|c|c|c|c|}
\hline & \multirow{2}{*}{$\begin{array}{c}\text { Total } \\
\text { admissions }\end{array}$} & \multicolumn{3}{|c|}{ Coma grade } & \multirow{2}{*}{$\begin{array}{c}\text { Oro- } \\
\text { pharyngeal } \\
\text { airway }\end{array}$} & \multirow{2}{*}{$\begin{array}{l}\text { Endo- } \\
\text { tracheal } \\
\text { tube }\end{array}$} & \multirow{2}{*}{$\begin{array}{l}\text { Venti- } \\
\text { lator }\end{array}$} \\
\hline & & 2 & 3 & 4 & & & \\
\hline Alcohol & 905 & $65(7 \cdot 2)$ & $64(7 \cdot 1)$ & $45(5 \cdot 0)$ & $24(2 \cdot 7)$ & $33(3 \cdot 6)$ & $10(1 \cdot 1$ \\
\hline No alcohol & 1963 & $120(6 \cdot 1)$ & $163(8 \cdot 3)$ & $90(4 \cdot 6)$ & $76(3.9)$ & $51(2 \cdot 6)$ & 271.4 \\
\hline
\end{tabular}

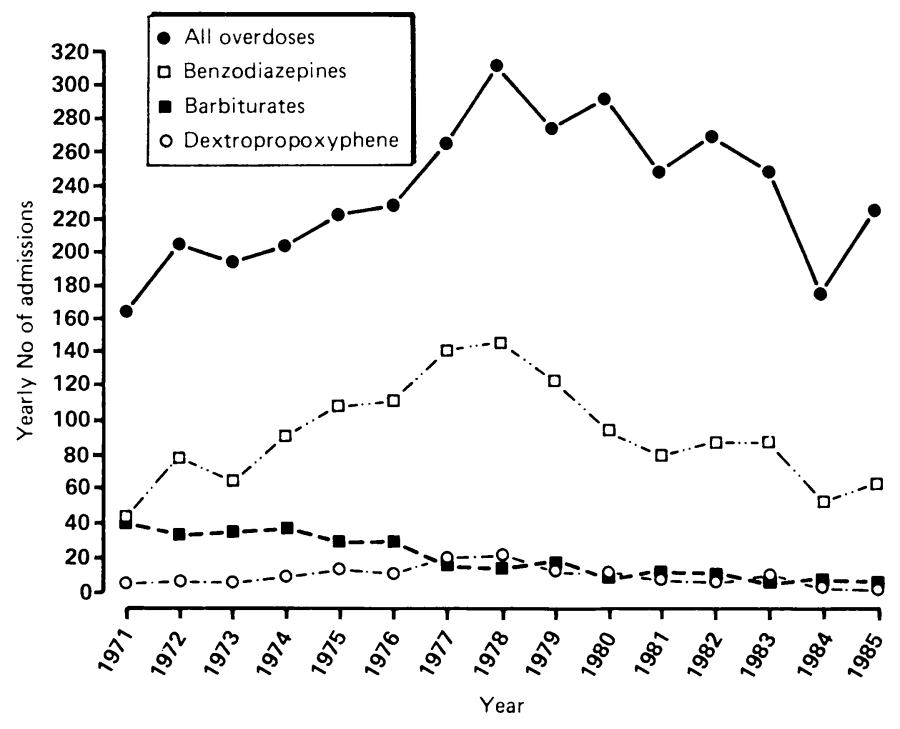

FIG 2-Yearly admission rates for self poisoning with associated trends in incidences of benzodiazepine, barbiturate, and dextropropoxyphene overdoses.

\section{Discussion}

This study shows that there was a significant increase in the frequency of alcohol intake in association with self poisoning during the two years after the liberalisation of Scotland's liquor licensing laws in 1976. During the six years after the change in the law compared with the six years before the proportion of male patients taking alcohol with their overdose almost doubled, while that of female patients more than doubled. We are not aware of any other firm evidence suggesting that the change in the law had a deleterious effect, though an increase in the alcohol intake of previously heavy drinkers has been recognised. ${ }^{9}$

It has been suggested that alcohol intake has an aetiological role in self poisoning. ${ }^{10}$ Alcohol reduces inhibitions and powers of reasoning, which may precipitate an overdose. A similar mechanism has been suggested to explain the high incidence of self poisoning with benzodiazepines and other psychotropic drugs. ${ }^{11}$ Increased alcohol consumption by the population at risk of self poisoning might therefore account for the observed increase in total admission rates after the change in the licensing law. The more recent fall in admission rates is not confined to Scotland and may reflect the decreased prescribing of benzodiazepines which has occurred throughout the United Kingdom. ${ }^{12}$

It has been stated that overdoses tend to be more serious, and sometimes unexpectedly fatal, when even moderate amounts of alcohol are taken concurrently. ${ }^{13} \mathrm{We}$ found no evidence to support this. There was no increase in the proportion of patients with grade 3 or 4 coma after 1976, and there was no significant difference in grade of coma between those who took alcohol and those who did not. Similarly, no definite association was found when the numbers of patients requiring special measures for care of the airway or artificial ventilation were considered. Other recent studies have also failed to find an association between alcohol intake and severity of 
poisoning ${ }^{14}$ and have shown a decreasing need for intensive care since 1978. ${ }^{15}$

Because of the change in types of drugs commonly taken in overdose over the past 15 years it may no longer be possible to detect an association between alcohol intake and severity of poisoning. Benzodiazepines, barbiturates, and dextropropoxyphene, all of which interact adversely with alcohol, ${ }^{5-7}$ now account for a smaller proportion of overdoses than before. Furthermore, it has become increasingly recognised that alcohol has pharmacological actions which may moderate the effects of certain types of drug overdose. In the acute phase alcohol may decrease the severity of self poisoning by decreasing the intestinal absorption of the drug taken in overdose.$^{16}$ In more chronic usage alcohol may cause tolerance to the depressive effects of an overdose on the central nervous system and by inducing hepatic enzyme activity enhance the rate of drug metabolism.

Thus, though there appears to have been no increase in the severity of overdoses associated with increasing alcohol use, there has been a rise in total admission rates. Overdoses associated with alcohol tend to occur at night and therefore impose a considerable workload on casualty departments and acute admitting units.

\section{References}

1 Clayson C. Report of the departmental committee on Scoutish licensing law. Edinburgh: HMSO, 1972. 2 Duffy JC, Plant MA. Scotland's liquor licensing changes: an assessment. BrMed f 1986;292:36-9. 3 Eagles JM, Besson JA. Scotland's liquor licensing changes. Br Med f 1986;292:486.

4 Fleiss JL. Statistical methods for rates and proportions. 2nd ed. Chichester: Wiley, 198

Morland J, Seteklein J, Haffner JFW, et al. Combined effects of diazepam and ethanol on mental and psychomotor function. Acta Pharmacol Toxicol (Copenh) 1974;34:5-15.

6 Melville KI, Joron GE, Douglas D. Toxic and depressant effects of alcohol given orally in combination with glutethimide or secobarbital. Toxicol Appl Pharmacol 1966;9:363-75.

Young RE, Lawson AAH. Distalgesic poisoning: cause for concern. Br Med f 1980;280: 1045-7. 8 Matthew H, Lawson AAH. Acute barbiturate poisoning-a review of two years' experience. Qf Med 1966;35:539-52.

9 Knight I, Wilson P. Scottish licensing laws. London: Office of Population Censuses and Survevs, 1980.

10 Morgan HE, Burns-Cox CJ, Pocock H, Pottle S. Deliberate self-harm: clinical and socioeconomic characteristics of 368 patients. Br 7 Psychiatry 1975;127:564-74

1 Prescott LF, Highley MS. Drugs prescribed for self-poisoners. Br Med 7 1985;290:1636-9.

12 Brewer C, Farmer R. Self-poisoning in 1984: a prediction that didn't come true. Br Med $\mathrm{f}$ 1985;290:391.

13 McInnes ET. Interactions that matter, alcohol. Prescribers' foumal 1985;25:87-90

14 Rangno RE, Dumont CH, Sitar DS. Effects of ethanol ingestion on outcome of drug overdose. Crit Care Med 1982;10:180-5.

15 McAleer JJA, Murphy EJJ, Taylor RH, Moran JLC, O'Connor FA. Trends in the severity of selfpoisoning. $\mathcal{F} R$ Soc Med 1986;79:74-5.

16 Ritchie JM. The aliphatic alcohols. In: Gilman AG, Goodman LS, Rall TW, Murad F, eds. The pharmacological basis of therapeutics. 7th ed. London: Collier McMillan, 1985.

(Accepted 21 October 1986)

\author{
BARRIE M MARGETTS, \\ LAWRENCE J BEILIN, \\ ROBERT VANDONGEN,
} BRUCE K ARMSTRONG trial}

Vegetarian diet in mild hypertension: a randomised controlled

\begin{abstract}
In a randomised crossover trial 58 subjects aged $30-64$ with mild untreated hypertension were allocated either to a control group eating a typical omnivorous diet or to one of two groups eating an ovolactovegetarian diet for one of two six week periods.

$A$ fall in systolic blood pressure of the order of $5 \mathrm{~mm} \mathrm{Hg}$ occurred during the vegetarian diet periods, with a corresponding rise on resuming a meat diet. The main nutrient changes with the vegetarian diet included an increase in the ratio of polyunsaturated to saturated fats and intake of fibre, calcium, and magnesium and a decrease in the intake of protein and vitamin $B_{12}$. There were no consistent changes in urinary sodium or potassium excretion or body weight.

In untreated subjects with mild hypertension, changing to a vegetarian diet may bring about a worthwhile fall in systolic blood pressure.
\end{abstract}

\footnotetext{
National Health and Medical Research Council Research Unit in Epidemiology and Preventive Medicine, University Department of Medicine, Queen Elizabeth II Medical Centre, Nedlands 6009, Western Medicine,

BARRIE M MARGETTS, PHD, research officer BRUCE K ARMSTRONG, DPHIL, director

Department of Medicine, University of Western Australia, Royal Perth Hospital, Perth 6001, Western Australia

LAWRENCE J BEILIN, MD, professor of medicine

ROBERT VANDONGEN, MD, associate professor of medicine

Correspondence to: Dr Barrie M Margetts, MRC Environmental Epidemiology Unit, University of Southampton, Southampton General Hospital, Southampton SO9 4XY.
}

\section{Introduction}

A blood pressure lowering effect of an ovolactovegetarian diet has been suggested by studies reporting a smaller rise in blood pressure with age in Seventh Day Adventist vegetarians ${ }^{1}$ and macrobiotic vegetarians ${ }^{2}$ than in the general population. This effect appears to be independent of differences in body weight and other differences in lifestyle, as Seventh Day Adventist vegetarians also have lower blood pressures than Mormon omnivores, who in common with Seventh Day Adventists also avoid alcohol, tobacco, and caffeine. ${ }^{3}$ More direct evidence comes from a controlled trial of a vegetarian diet in healthy normotensive meat eaters, which found a diet related reduction in systolic blood pressure of $5-6 \mathrm{~mm} \mathrm{Hg}$ independent of changes in body weight. ${ }^{4}$

We have examined the effect of a vegetarian diet in subjects with mild hypertension.

\section{Subjects and methods}

Between June and November 1983 the National Heart Foundation of Australia conducted a risk factor prevalence survey in which 1788 residents of Perth, Western Australia, aged 25 to 64 were selected at random for measurement of coronary risk factors. Blood pressures were measured in duplicate on the right arm after five minutes' sitting by a trained nurse using a standard mercury sphygmomanometer. All subjects whose blood pressures were between 150 and $200 \mathrm{~mm} \mathrm{Hg}$ systolic or between 90 and $115 \mathrm{~mm} \mathrm{Hg}$ diastolic and who were not currently being treated for hypertension (inclusion criteria) were asked to return a week later for a second blood pressure measurement with a view to possible participation in the dietary trial.

At the second and all subsequent visits blood pressures were measured in duplicate on the right arm after five minutes' sitting using an automatic oscillometric device (Dinamap recorder). If the blood pressure readings still met the inclusion criteria at this and a subsequent visit a week later subjects 